\title{
IMPACT OF PROBLEM SOLVING SKILLS TO ACHIEVE IN MATHEMATICAL ABILITY OF THE FEMALE STUDENTS OF SECONDARY LEVEL OF EDUCATION
}

\author{
Satyajit Sarkar \\ Research Scholar, Seacom Skills University, Bolpur, West Bengal.
}

\begin{abstract}
Education is the stepping stone among the pupil at large. While secondary level is a stage ahead in this wide sense. Problem solving skills enhance achievement orientation specifically in the context at mathematics and its ability to explore in the female students. The purpose of the study is to find out the problem solving skills on achievement in mathematics, female students of secondary level of education. To maintain the eventuality, 400 samples were collected from four high schools at Habra Block II, North 24 Parganas district and Haringhata block, Nadia district. These samples were taken from class ix and class $x$ of the age group 14-17 years. Stratified random sampling method were followed for collection of Data. The statistical methods Mean, Standard deviation, Pearson product moment of correlation coefficient are applied. Finally this study concludes that the problem solving skills has a positive impact on achievement in Mathematics of the Female students of secondary level of education.
\end{abstract}

Keywords-- Achievement, Education, Mathematics, Problem, skill.

\section{INTRODUCTION:}

Modern technology cannot be developed without mathematics. It is a basic science for developing the creative and logical thinking. It is also science of calculation, measurement and magnitude. Its major role for development in every field of life. It involves to solve a problem for getting solution. Thorough the learning and solving mathematics, everyone improves reasoning, problem solving skills and thinking skills. Mathematics makes major role for academic achievement of student. Education system does not progress without progress of mathematical knowledge.

Problem solving skills help everyone to identify the source of a problem and also evaluate the problem. There are lot of importance of problem solving skills in mathematics. It makes the major role to develop the skills of solving mathematical problem. By problem solving skills, different types of problem can be solved in different ways. It is used to solve in different problem in different subjects like mathematics, physics, chemistry, biology, economics etc. The important role of problem solving skills is the teaching in mathematics. Therefore the development of any one's problem skills has been executed to solve new mathematical problem. Teacher need to help the students to develop their problem solving skills.

\section{REVIEW OF RELATED LITERATURE:}

Many researchers explored Problem solving skills as a specific ground to develop mathematical ability of students of secondary level of education.

Ganesan (2000), describes in his thesis on the topic of the research was based on the topic of effective of problem solving modelling in enhancing students achievement in mathematics. The study was emphasized upon problem solving modelling make a positive role in achievement of student in mathematics.

Louange and Bana (2010) describes in his thesis on the topic of the research was based on the relationship between the number sense and problem solving abilities of the age of 7 years students that emphasized upon that very powerful correlation between the number sense and problem solving capability of the student of the age of 7 years.

Dhyani Vidhi (2014) emphasized the intelligence and problem solving abilities of secondary level students. It was revealed that the intelligence and problem solving ability of secondary level student was correlated.

Kalaimathi and Hemlata (2015) studied on relationship between problem solving ability and working memory of secondary school students. The study was revealed that the problem solving ability helps students in increasing attention and working memory

Susilowati and Anam (2017) studied on the improving the scientific reasoning and problem solving of student by $5 \mathrm{E}$ (engagement, explanation, exploration, elaboration, evaluation) leaning model. The study was revealed that there was a good correlation between scientific ability and problem solving skills. 


\section{DOI: 10.17148/IARJSET.2021.8828}

Problem solving makes of an effort to find out the difficulties of different types of problem. Sometimes it is difficult to achieve the solution of problem immediately (Nisraeni\&Arifanti,2018).

\section{OBJECTIVES:}

i) To study the impact of Problem Solving Skills of Female students at secondary level at Education.

ii) To find out the Achievement of Mathematics of Female students at secondary level of education.

iii) To find out the impact of Problem Solving Skills with Mathematical achievement.

\section{HYPOTHESIS:}

i) There is any significant impact of problem solving skills of achievement through mathematics of female students at secondary level of education.

ii) There is any significance difference of problem solving skills and achievement in mathematics of female students at secondary level of education..

\section{METHODOLOGY:}

Sample consisted of 400 female students from class ix and x of North 24 Parganas district and Nadia district. Stratified random sampling method were used for collecting data.The tools of the study were used

i) The 'Problem solving ability test' made by L. N. Dubey and Dr C.P Mathur.

ii) The 'Mathematics achievement test' made by L. N. Dubey.

Data are collected by going the girls' and conditional schools of North 24 Parganas and Nadia districts.

\section{A) FOR FEMALE STUDENTS OF NORTH 24 PARGAN \\ 6. RESULTS AND ANALYSIS:}

a) FREQUENCY ACHIEVEMENT OF FEMALE STUDENTS FOR NORTH 24 PARGANAS.

Table 1

\begin{tabular}{|c|c|c|c|c|c|c|c|c|}
\hline \multirow{3}{*}{ Parameter } & \multicolumn{8}{|c|}{ Categories of female achievement } \\
\hline & \multicolumn{2}{|l|}{ A } & \multicolumn{2}{|c|}{$\mathrm{B}$} & \multicolumn{2}{|c|}{$\mathrm{C}$} & \multicolumn{2}{|l|}{$\mathrm{D}$} \\
\hline & Total & $\%$ & Total & $\%$ & Total & $\%$ & Total & $\%$ \\
\hline Problem solving ability & 22 & 11 & 48 & 24 & 55 & 27.5 & 75 & 37.5 \\
\hline Mathematical ability & 23 & 11.5 & 51 & $\begin{array}{l}25 . \\
5\end{array}$ & 48 & 24 & 78 & 39 \\
\hline
\end{tabular}

\section{A MEANS 80\%-100\% MARKS, B MEANS 60\% -79\% MARKS, C MEANS 40\% -59\% MARKS,. D MEANS BELOW 40\% MARKS}

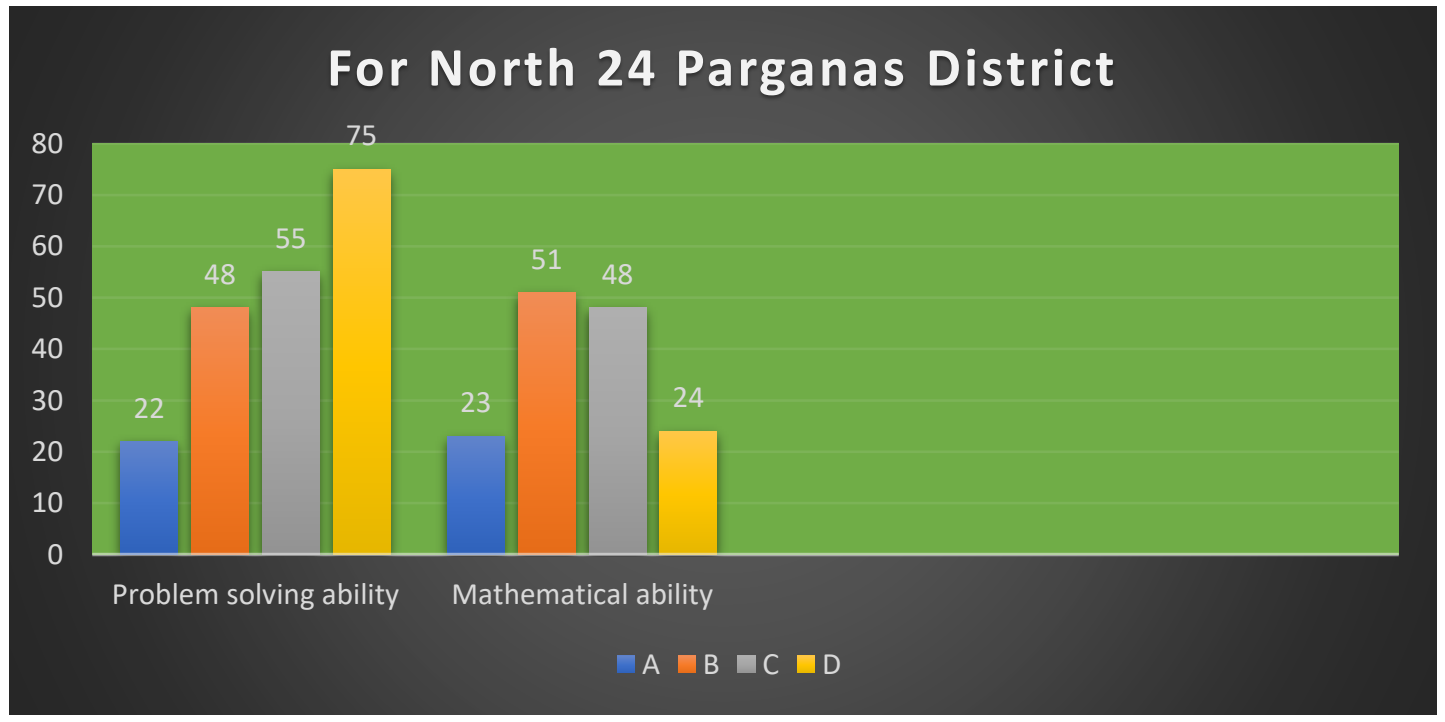

Figure. 1. frequency achievement of studied students

200 female students have been selected of class ix and class x of different coeducational and girls' schools in North 24 Parganas district. Two sets of questions paper of Problem solving ability test, Mathematical achievement test have been 
Vol. 8, Issue 8, August 2021

DOI: $10.17148 /$ IARJSET.2021.8828

given to these students of class ix and x. From the table, A indicates $80 \%-100 \%$ marks, B indicates $60 \%-79 \%-$ marks, $\mathrm{C}$ indicates 40\% - 59\% marks, D indicates below $40 \%$ marks. 200 students have answered the two sets of questions of Problem solving ability test and Mathematical achievement test. For Problem solving ability test, 22 i.e $11 \%$ students have scored A category marks, 48 i.e $24 \%$ students have scored B category marks, 55 ie $27.5 \%$ students have scored C category marks, 75 i,e 37.5\% students have scored D category marks. For Mathematical ability test, 23 i.e $11.5 \%$ students have scored A category marks, 51 i.e 25.5 students have scored B category marks, 48 i.e $24 \%$ students have scored C category marks, and 78 i.e $39 \%$ students has scored D category marks.

\section{b) AGE WISE FREQUENCY DISTRIBUTION OF THE STUDIED STUDENTS}

Table2

\begin{tabular}{|c|c|c|c|}
\hline \multirow{2}{*}{$\begin{array}{l}\text { District } \\
\text { name }\end{array}$} & \multirow[t]{2}{*}{ Categories } & \multicolumn{2}{|c|}{ For female } \\
\hline & & Total & $\%$ \\
\hline \multirow[t]{2}{*}{$\begin{array}{l}\text { North } 24 \\
\text { Parganas }\end{array}$} & $\begin{array}{ll}\text { Age } & 14-16 \\
\text { years }\end{array}$ & 118 & 59 \\
\hline & $\begin{array}{l}\text { Age above } 16 \\
\text { years }\end{array}$ & 82 & 41 \\
\hline
\end{tabular}

From this table it is shown that 118 i.e.59\% female students of secondary level belong to age group of age 14 to 16 years in North 24 Pargana district and 82 i.e. $41 \%$ female students of secondary level belong to above are 16 years at the same district.

\section{c ) THE CORRELATION OF PROBLEM SOLVING ABILITY AND MATHEMATICAL ABILITY}

Table 3

\begin{tabular}{|l|l|l|l|l|l|}
\hline Categories & $\begin{array}{l}\text { Mathematical } \\
\text { Ability(X) }\end{array}$ & $\begin{array}{l}\text { Problem solving } \\
\text { Ability(Y) }\end{array}$ & $\mathrm{X}^{2}$ & $\mathrm{Y}^{2}$ & $\mathrm{XY}$ \\
\hline A & 23 & 22 & 529 & 484 & 462 \\
\hline B & 51 & 48 & 2601 & 2304 & 2256 \\
\hline C & 48 & 55 & 2304 & 3025 & 3025 \\
\hline D & 78 & 75 & 6084 & 5625 & 5775 \\
\hline$\sum$ & $\sum \mathrm{X}=200$ & $\sum \mathrm{Y}=200$ & $\sum \mathrm{X}^{2}=11518$ & $\sum \mathrm{Y}^{2}=11438$ & $\sum \mathrm{XY}=11444$ \\
\hline
\end{tabular}

We know, $\mathrm{r}_{\mathrm{XY}}=\left(\mathrm{N} \sum \mathrm{XY}-\sum \mathrm{X} \sum \mathrm{Y}\right) / \sqrt{ }\left(\mathrm{N} \sum \mathrm{X}^{2}-\left(\sum \mathrm{X}\right)^{2}\right) \cdot \sqrt{ }\left(\mathrm{N} \sum \mathrm{Y}^{2}-\left(\sum \mathrm{Y}\right)^{2}\right)$

$\mathrm{N}=4, \sum \mathrm{X}=200, \sum \mathrm{Y}=200, \sum \mathrm{X}^{2}=11518, \sum \mathrm{Y}^{2}=11438, \sum \mathrm{XY}=11444$

Putting these value we get $\mathrm{r}_{\mathrm{XY}}=0.977$

The correlation coefficient is very high. Both are highly correlated. The female students who have good mathematical ability has good problem solving ability and vice versa.

B) FOR FEMALE STUDENTS OF NADIA DISTRICT a) FREQUENCY ACHIVEMENT OF THE FEMALE OF THE STUDIED SCHOOL

Table 4

\begin{tabular}{|l|l|l|l|l|l|l|l|l|}
\hline \multirow{2}{*}{ Parameter } & \multicolumn{7}{|c|}{ Categories of female achievement } \\
\cline { 2 - 10 } & \multicolumn{2}{|c|}{ A } & \multicolumn{2}{|c|}{ B } & \multicolumn{2}{|c|}{ C } & \multicolumn{2}{|c|}{ D } \\
\cline { 2 - 9 } & Total & $\%$ & Total & $\%$ & Total & $\%$ & Total & $\%$ \\
\hline $\begin{array}{l}\text { Problem } \\
\text { solving ability }\end{array}$ & 22 & 11 & 47 & 23.5 & 50 & 25 & 81 & 40.5 \\
\hline $\begin{array}{l}\text { Mathematical } \\
\text { ability }\end{array}$ & 27 & 13.5 & 47 & 23.5 & 55 & 27.5 & 71 & 35.5 \\
\hline
\end{tabular}


DOI: $10.17148 /$ IARJSET.2021.8828

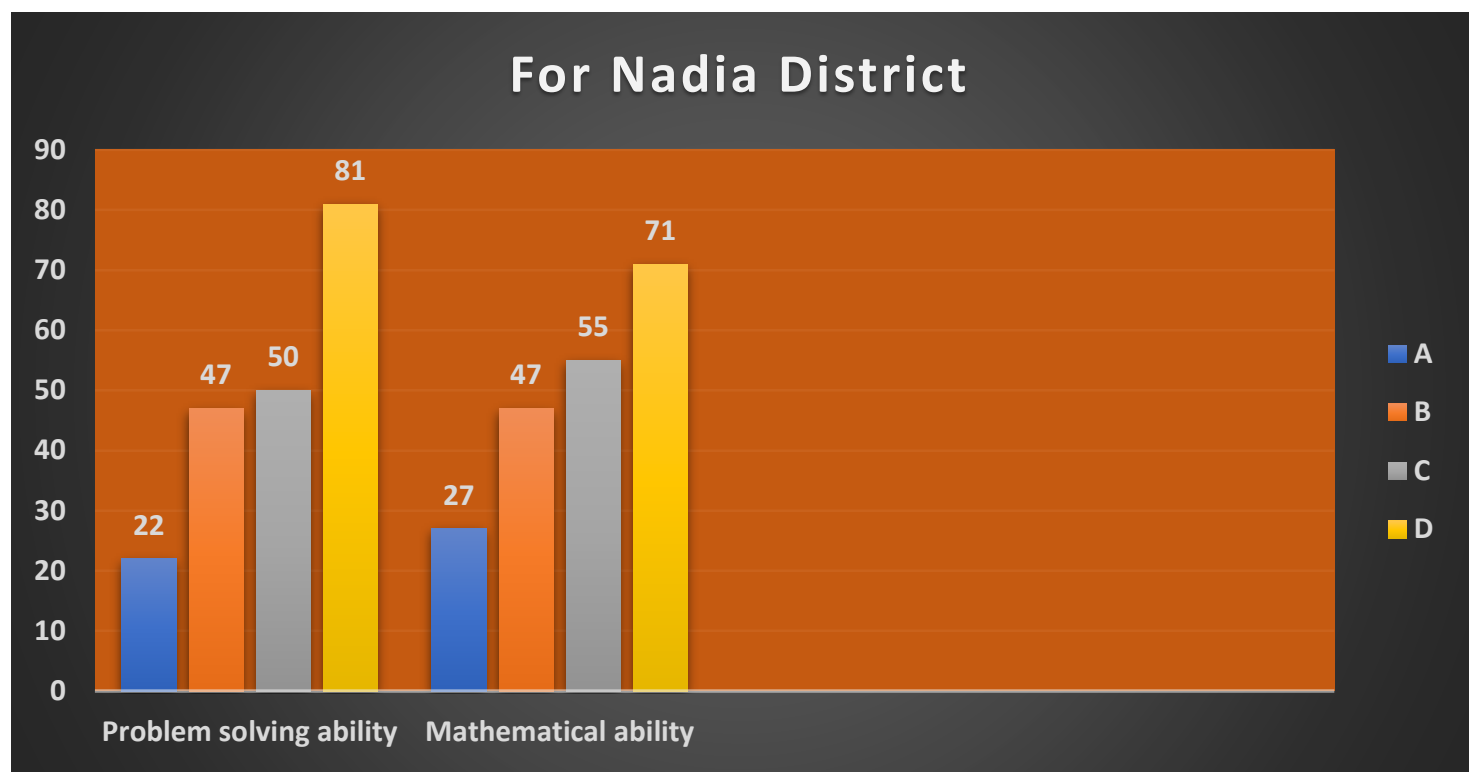

Figure. 2. Frequency achievement of studied students

200 female students have been selected of class ix and class x of different coeducational and girls' schools from Nadia district. Two sets of questions papers of Problem solving ability test, Mathematical ability test have been given to these student of class ix and $x$ in different school. From the table, A indicates $80 \%-100 \%$ marks, B indicates $60 \%-79 \%$ marks, $\mathrm{C}$ indicates 40\% - 59\% marks, D indicates 40\% marks. 200 students have answered the two sets of questions of Problem solving ability test and Mathematical ability test. 22 i.e $11 \%$ students have scored A category marks, 47 i.e $23.5 \%$ students have scored B category marks, 50 i.e $25 \%$ students have scored C category marks, 81 i.e 40.5 students have scored D category marks. For Mathematical ability test, 27 i.e 13.5\% students have scored A category marks, 47 i.e $23.5 \%$ students have scored B category marks, 55 i.e $27.5 \%$ students have scored C category marks, and 71 i.e $35.5 \%$ students have scored D category marks

\section{b) AGE WISE FREQUENCY DISTRIBUTION OF THE STUDIED STUDENTS}

Table 5

\begin{tabular}{|l|l|l|l|}
\hline District name & Categories & \multicolumn{2}{|c|}{ For female } \\
\cline { 3 - 4 } & & Total & $\%$ \\
\hline Nadia & Age 14-16 years & 125 & 62.5 \\
\cline { 2 - 4 } & $\begin{array}{l}\text { Age above 16 } \\
\text { years }\end{array}$ & 75 & 37.5 \\
\hline
\end{tabular}

From this table, it is shown that 125 i.e. $62.5 \%$ female students of secondary level belong to age group of age 14 to 16 years in Nadia district and 75 i.e 37.5. \% female student of secondary level belong to above age 16 years at the same district.

c) ABILITY THE CORRELATION OF PROBLEM SOLVING AND MATHEMATICAL ABILITY

Table 6

\begin{tabular}{|l|l|l|l|l|l|}
\hline Categories & $\begin{array}{l}\text { Problem Solving } \\
\text { Ability(X) }\end{array}$ & $\begin{array}{l}\text { Mathematical } \\
\text { Ability(Y) }\end{array}$ & $\mathrm{X}^{2}$ & $\mathrm{Y}^{2}$ & $\mathrm{XY}$ \\
\hline A & 22 & 27 & 484 & 729 & 594 \\
\hline B & 47 & 47 & 2209 & 2209 & 2209 \\
\hline C & 50 & 55 & 2500 & 3025 & 2750 \\
\hline D & 81 & 71 & 6561 & 5041 & 5751 \\
\hline$\sum$ & $\sum \mathrm{X}=200$ & $\sum \mathrm{Y}=200$ & $\sum \mathrm{X}^{2}=11754$ & $\sum \mathrm{Y}^{2}=11004$ & $\sum \mathrm{XY}=11304$ \\
\hline
\end{tabular}

We know $r_{X Y}=\left(N \sum X Y-\sum X \sum Y\right) / \sqrt{ }\left(N \sum X^{2}-\left(\sum X\right)^{2}\right) \cdot \sqrt{ }\left(N \sum Y^{2}-\left(\sum Y\right)^{2}\right)$

Here $\mathrm{N}=4, \sum \mathrm{X}=200, \sum \mathrm{Y}=200, \sum \mathrm{X}^{2}=11754, \sum \mathrm{Y}^{2}=11004, \sum \mathrm{XY}=11304$

Putting these values we get $r_{X Y}=0.982$

The correlation coefficient is very high. Both are highly correlated. The female students who has good problem solving ability, has good mathematical ability and vice versa. 


\title{
International Advanced Research Journal in Science, Engineering and Technology
}

\author{
Vol. 8, Issue 8, August 2021
}

\section{DOI: 10.17148/IARJSET.2021.8828}

\section{DISCUSSION:}

As a result to this research of above two correlation coefficient table from North 24 Parganas district and Nadia district, the correlation coefficient between problem solving ability and mathematical ability is very high. Those female students who are very strong in problem solving skills, are also strong in mathematical ability. It is said that problem solving ability has good impact on mathematics achievement of female students. For development of subject of mathematics, every student should develop of problem solving skills. Good performance of mathematics is very necessary for development of other subject of science and also for technology.

Finding by the analysis of correlation coefficient, it shows that

i) There is no significance difference of the Problem Solving skills and achievement of mathematics of female students of secondary level.

ii) There is a high impact of problems solving skills on achievement in Mathematics of Female students of secondary level.

\section{CONCLUSION:}

From the result of data analyses it can be shown that problem solving skills and achievement in mathematics are very correlated. If the problem solving skills of a student is poor then the mathematical ability of the student is also poor. It shows that there is improvement of achievement of mathematics of female students depending on problem solving skills.

Hence the research establishes that that the problem solving skills has a positive impact on Achievement in Mathematics of the Female students of secondary level of education.

\section{REFERENCES:}

[1] Anderson, j. (2009). 'Mathematics curriculum development and the role of problem solving'. ACSA Conference, The University of Sydney. [2] Bahar, A. \& Makar, C.J.(2015). Cognitive Background of Problem solving e:A Comparison of open-ended vs Closed Mathematics Problem. Eurasia Journal of Mathematics, Science \& Technology Education, 11(6), 1531-1546.

[3] Chang. C.Y.\& Taipei, Y.H.W.(2002). An exploratory study on students' problem-solving ability in earth science. International Journal of Science Education, 24(5), 441-451.

[4] Dhyani, Vidhi. (2014). 'A study of mathematical aptitude in relation to intellectual and problem solving ability of secondary student'. Ph. D Thesis in Department of education, S.S.J, Campus, Almora, Kumaun University, Nainital (Uttarakhand).

[5] Fabby, C., \& Koenig, K. (2015). 'Examining the relationship of scientific reasoning with physics problem solving'.Journal of STEM Education: Innovations and Research, 16(4),20.

[6] Ganesan. A. (2000). 'Effect of problem solving modelling in enhancing students achievement in mathematics”. Ph. D Thesis in Education, Ala University (Tamil Nadu)

[7] Kalaimathi,Dr(Mrs)., \& Hemlata,.(2015). 'A study on the relationship between problem solving ability and working memory of secondary school student'. Indian Journal of Research,4(8), 379-381.

[8] Kitsantas, A., Cheema, J., \& ware, H. W. (2011). 'Mathematics achievement: the role of homework and self-efficacy beliefs. Journal of Advanced Academics, 22(2), 310-339.

[9] Lason, A. E. (1994). Science Teaching and the Development of Thinking. California: Wadsworth Publishing Company.

[10] Lee, D.M. (1968). 'A study of specific ability and attainment in mathematics'. British Journal of Educational Psychology, 37, 137-189.

[11] McCoach, D. B., Gable, R.K., \& Madura, J.P.(2013). Instrument development in the affective domain. London, UK: Springer.

[12] Poly, G. (1988). How to solve it: Anew aspect of mathematical method, second edition, Princeton University Press.

[13] Santrock, j. W.(2011). Educational psychology (5 ${ }^{\text {th }}$ ed). New York, NY: McGraw Hill Companies.

[14] Susilowati, S.M.E.,\& Anam. K.(2017).'Improving Students' Scientific Reasoning and Problem Solving Skills by The 5E Learning Model'.

Biosaintifika: Journal of Biology \&Bology Education, 9(3), 506-512.

[15] Schoen, H.L.,\& Charles, R. I.(2003). Teaching mathematics through problem solving: Grades 6-12.Restom,Va:NCTM.

[16] Thiessen, D., \& Trafton, P. (1999). Learning through problems: Number sense and computational strategies, a resource for primary teachers. Portsmouth: Heinemann.

[17] Wajiha, A.H.(2000). 'Factors affecting academic achievement of IX standard students in mathematics', Unpublished Ph.D. Thesis in Education. Karnatak University(Karnatak).

[18] Hemalatha B D. "Footprints of Educational Technology in Higher Education". International Research Journal on Advanced Science Hub, 3, Special Issue ICITCA-2021 5S, 2021, 21-26.

[19] Sarbjot kaur. "Academic Achievement and Creativity among 10th Class Students". International Research Journal on Advanced Science Hub, 3 , Special Issue ICARD-2021 3S, 2021, 158-161. doi: 10.47392/irjash.2021.085

[20] R. G. Deshmukh. "Increasing Girls participation in Physics Education". International Research Journal on Advanced Science Hub, 2, Special Issue ICARD 2020, 2020, 198-201. doi: 10.47392/irjash.2020.119

[21] Salma Begum; Sampurna P.. "A Study on growth in Technology and Innovation across the globe in the Field of Education and Business". International Research Journal on Advanced Science Hub, 3, Special Issue 6S, 2021, 148-156. 